\title{
Psychometric Characteristics of the Serbian Version of the Leicester Cough Questionnaire in Sarcoidosis Patients
}

\author{
Branislav S. Gvozdenović1, Violeta V. Mihailović-Vučinić2,3, \\ Nikola B. Marić ${ }^{2}$ \\ ${ }^{1}$ PPD Serbia, Pharmacovigilance Department, Belgrade, Serbia \\ ${ }^{2}$ Clinic for Pulmonology, Clinical Centre of Serbia, Belgrade, Serbia \\ ${ }^{3}$ Faculty of Medicine, University of Belgrade, Serbia \\ ${ }^{4}$ QA Department, Health Centre Valjevo, Valjevo, Serbia
} Mira H. Vuković ${ }^{4}$, Mihailo I. Stjepanovićc,3, Strahinja V. Mihailović ${ }^{2}$,

\section{SUMMARY}

Introduction: Cough is frequent symptom in sarcoidosis and there are no specific tools for measurement of its severity in Serbia.

Aim: The goal of this study was to translate and validate the Serbian version of the Leicester Cough Questionnaire (LCQ) in a population of sarcoidosis patients.

Methods: After the LCQ forward-backward translation process, in the cross-sectional study in 275 (180 female) sarcoidosis patients Serbian version of the LCQ was administered together with other standardized instruments for measurement of Patient Reported Outcomes (PROs) - symptoms of dyspnea (assessed by MRC and Borg scales) and fatigue (measured by Fatigue Assessment Scale and List of Daily Activities), and patients' health status (assessed by generic tool-15D). Pulmonary function tests (spirometry and diffusing capacity for carbon monoxide) were also measured.

Results: Serbian LCQ version showed excellent internal consistency (Cronbach's alpha of its different scores ranged between 0.901 for physical domain and 0.951 for the total score). Concurent validity assessed by correlations of all LCQ scores with other PROs and pulmonary function tests was very good, since all these correlations were statistically significant.

Conclusions: Our results confirmed that the Serbian version of LCQ is a valid instrument to monitor the influence of chronic cough on quality of life in sarcoidosis patients.

Keywords: sarcoidosis, cough, dyspnea, fatigue, pulmonary function tests 


\section{INTRODUCTION}

Sarcoidosis is a chronic multisystem granulomatous disease of unknown origin that is most commonly present in the lungs but may also involve any other organ [1].

Patients with pulmonary sarcoidosis may have symptoms related directly to the chest such as dyspnea on exertion, chest pain, chest discomfort, cough, and wheeze. Patients may also develop symptoms related to extrapulmonary organ involvement. In addition, sarcoidosis may cause constitutional symptoms such as fatigue, fever, anorexia, weight loss, generalized weakness, and pain that are not attributable to involvement of any specific organ $[2,3]$.

Nowadays design of most of the international clinical drug trials includes $\mathrm{Pa}$ tient-Reported Outcomes (PROs) as study endpoints, and their changes during treatment period represent either secondary and exploratory (in phases II or IIIa) or even primary (in phases IIIb and IV) study objectives. Food and Drug Administration (FDA) defines PROs as measurement of any aspect of a patient's health status that comes directly from the patient, without interpretation of the patient's responses by a physician or anyone else [4]. PROs encompass symptoms and signs of disease, treatment satisfaction and quality of life (QoL) of patients. This is increasingly observed as the regulatory authorities' requirement due to several limitations of the objective disease outcomes, like pulmonary function tests or radiographic findings. Moreover, numerous studies showed that correlations between PROs as subjective outcomes and objective outcomes are rather mild or moderate or even do not exist at all [5].

The assessment of all endpoints should be possible in all subjects in a consistent and reproducible manner, using the same techniques applicable to all subjects in the study. Thus, questionnaires have been developed and validated in order to assess PROs in a standardized way.

Recently, more attention has been paid to the cough in patients with sarcoidosis and we now have a validated tool - Leicester Cough Questionnaire (LCQ) for measuring this important symptom [6]. Currently only a few studies used LCQ for assessing cough in sarcoidosis patients [7-9].

LCQ is a 19 -item validated specific
QoL measure of cough over the period of privious two weeks [6]. Its scores can be calculated in 3 domains covering physical (8 items), psychological (7 items), and social (4 items) aspect of chronic cough, in addition to the total score. It evaluates the impact of cough on patients' quality of life. It takes 5 to 10 minutes to complete. Scores are calculated by domain (range from 1 to 7 ) and then added to obtain the total score (range from 3 to 21), with higher scores indicating a better QoL.

The LCQ has been translated into several languages including Dutch, Korean, Lithuanian, Mandarin, Polish, Portuguese, German and Spanish, and validated in corresponding cohorts [10-19]. It has been also validated for different diseases, like chronic cough itself, cystic fibrosis including affected children, bronchiectasis, COPD [17,20-22], and recently for sarcoidosis [8]. A validated Serbian version does not exist, so our aim was to translate and validate Serbian version of the LCQ in sarcoidosis patients in order to provide an instrument for future multinational studies on chronic cough in sarcoidosis patients in particular.

\section{METHODS}

The original English version of the LCQ was translated into Serbian language in a forwardbackward approach. Three authors (BSG, VMV, MHV) independently translated the LCQ nad mutually agreed about the final working Serbian version. After that the professional translator experienced and familiar with medical terminology performed back-translation of the agreed Serbian version. After comparing back-translated LCQ version with the original one, the authors agreed that there was no need for further corrections of the Serbian version. So, this Serbian version of the LCQ was initially administered among ten sarcoidosis patients at the Clinic for Pulmonology, Clinical Center of Serbia in Belgrade, Serbia, in order to assess their understanding of each particular question. All of them understood questions from the questionnaire very well and had no additional questions. Therefore, the implemented version of the LCQ did not need any modifications and we accepted it as the final Serbian version.

Most patients recruited in this cross- 
sectional study in the period from April to November 2018 are members of the Serbian Association of Sarcoidosis, which now includes more than 2,000 patients with different clinical forms of sarcoidosis. We enrolled 275 biopsy positive sarcoidosis patients diagnosed at the Clinic for Pulmonary Diseases of the Clinical Centre of Serbia in Belgrade, Serbia. All subjects were $\geq 18$ years old and they did not have any associated ilnesses that could influence their health status (those with significant comorbidity, like cardiac or respiratory disorders other than sarcoidosis, were excluded from analysis). These patients were examined during regularly scheduled clinical visits and the patients voluntarily completed the self-administered PROs and performed pulmonary function testing.

This study was approved by the institution's ethics committee and all patients consented to participation.

Validity of the Serbian version of the LCQ was examined by the assessment of internal consistency (calculating the Cronbach's Alpha coefficient) and concurrent validity (correlating the LCQ scores with other standardized instruments for measurement of symptoms of dyspnea and fatigue, health status and pulmonary function parameters in sarcoidosis patients).
Following PROs were administered: 1) Dyspnea instruments: Modified Medical Research Council (MRC) Dyspnea Scale [23] and Borg dyspnea category-ratio-10 scale (CR-10) [24],

2) Fatigue questionnaires: Fatigue Assessment Scale (FAS) [25] and Daily Activity List (DAL) [26], and

3) QoL scales: LCQ [6] and General health status questionnaire 15D [27].

Modified Medical Research Council (MRC) Dyspnea Scale classifies subjects into one of five categories according to their degree of dyspnea when performing certain activities [23]. Scores range from the 0 to 4 , with the higher scores indicating more severe dyspnea. We previously used it in patients with sarcoidosis $[28,29]$.

Borg dyspnea category-ratio-10 scale (CR-10) [24] is an 11-point scale on which dyspnea is graded from 0 (nothing at all) to 10 (maximum). It is widely used in clinical trials in different respiratory and cardiovascular diseases.

Fatigue was assessed by the standardized Fatigue Assessment Scale (FAS) [25]. The FAS is a 10-item self-report fatigue questionnaire. The response scale is a 5-point Likert scale ( 1 never to 5 always). Total scores on the FAS can range from 10 to 50, with high scores
Table 1. Descriptive statistics for PRO scores and pulmonary function tests

$\mathrm{X}=$ mean;

$\mathrm{SD}=$ standard deviation;

MRC = Modified Medical Research Council Dyspnea Scale;

Borg $=$ Borg dyspnea categoryratio-10 scale;

FAS-TS = Fatigue Assessment Scale - Total score;

$\mathrm{DAL}=$ List of Daily Activities;

$\mathrm{LCQ}=$ Leicester Cough Questionnaire;

$15 \mathrm{D}=$ Fifteen-dimensional measure of health-related quality of life;

$\mathrm{FEV}_{1}=$ Forced expiratory volume in one second;

FVC = Forced expiratory vital capacity;

PEF = Peak Expiratory Flow; DLCO = transfer factor of the lung for carbon monoxide.

\begin{tabular}{|c|c|c|}
\hline & $X \pm S D$ & Range \\
\hline Sex, $m / f$ & $95 / 180$ & \\
\hline Age, years & $50.13 \pm 11.07$ & $28-76$ \\
\hline Disease duration, years & $15.62 \pm 8.56$ & $1-40$ \\
\hline \multicolumn{3}{|l|}{ Dyspnea scores } \\
\hline MRC & $0.89 \pm 0.69$ & $0-3$ \\
\hline Borg & $1.43 \pm 1.54$ & $0-9$ \\
\hline FAS-TS & $24.55 \pm 6.23$ & $15-42$ \\
\hline DAL & $3.00 \pm 2.50$ & $0-10$ \\
\hline \multicolumn{3}{|l|}{ LCQ Scores } \\
\hline Total score & $16.94 \pm 3.68$ & $5.48-21$ \\
\hline Physical domain score & $5.48 \pm 1.18$ & $1.88-7.00$ \\
\hline Psychological domain score & $5.64 \pm 1.29$ & $1.86-7.00$ \\
\hline Social domain score & $5.82 \pm 1.33$ & $1.75-7.00$ \\
\hline 15D & $0.85 \pm 0.11$ & $0.49-1.00$ \\
\hline FEV $_{1}$ (\% predicted) & $99.60 \pm 20.02$ & $34-150$ \\
\hline FVC (\% predicted) & $108.52 \pm 17.40$ & $41-156$ \\
\hline $\mathrm{FEV}_{1} / \mathrm{FVC}$ & $76.57 \pm 8.51$ & $31.63-91.36$ \\
\hline PEF (\% predicted) & $105.61 \pm 21.79$ & $30-169$ \\
\hline DLCO (\% predicted) & $81.55 \pm 17.46$ & $37-111$ \\
\hline
\end{tabular}




\begin{tabular}{|l|c|c|}
\hline \multicolumn{1}{|c|}{ Criteria of drug imputability } & $\begin{array}{c}\text { Criteria of drug } \\
\text { imputability }\end{array}$ & Criteria of drug imputability \\
\hline Total Score All items $(1-15)$ & 19 & 0.951 \\
\hline Physical Items: $1,2,3,9,10,11,14,15$ & 8 & 0.901 \\
\hline Psychological Items: $4,5,6,12,13,16,17$ & 7 & 0.922 \\
\hline Social Items: $7,8,18,19$ & 4 & 0.918 \\
\hline
\end{tabular}

indicating more fatigue. FAS total score $<22$ indicates no fatigue. The psychometric properties (reliability and validity) of the FAS are good, and it was also shown in sarcoidosis patients $[30,31]$. The Serbian version proved to be valid in rheumatoid arthritis [32] and sarcoidosis [33].

The degree of limitation in daily life activities was evaluated with the Daily Activity List (DAL), a scale that was originally designed by Stewart and coworkers [26]. It has 11 items that are related to the usual activities that persons with good health can perform without particular effort. The number of positive responses comprises the DAL score and indicates the degree of impairment. The scale has been used in several studies in patients with chronic pulmonary diseases $[34,35,28]$.

We used the standardized questionnaire for the measuring of health status: a generic measure - The fifteen-dimensional measure scale of health-related quality of life (15D) [27]. $15 \mathrm{D}$ is a multiatributive instrument for measurement of health-related quality of life that was initially developed and validated in a large Finnish population. It consists of 15 different and mutually exclusive health dimensions, each represented by one item. The total questionnaire score ranges between 0 and 1 , where 1 signifies the highest level of health status. 15D was used in different diseases in many different countries. The Serbian version of $15 \mathrm{D}$ was previously used in patients with sarcoidosis where it demonstrated good psychometric measurement properties [28,36].

On the same day subjects completed the questionnaires and performed pulmonary function tests - spirometry and the transfer factor of the lung for carbon monoxide (DLCO). Spirometry parameters included pre-bronchodilator forced expiratory vital capacity (FVC), forced expiratory volume in one second $\left(\mathrm{FEV}_{1}\right), \mathrm{FEV}_{1} / \mathrm{FVC}$, peak expiratory flow (PEF) and it was measured with a pneumotachograph (Masterlab, Jaeger, Wurzburg, Germany). DLCO was measured using the single-breath method (Masterlab, Jaeger,
Wurzburg, Germany). The European Respiratory Society criteria for lung function impairments was used [37].

A probability value of $\mathrm{p}<0.05$ was considered to be statistically significant, and $\mathrm{p}$ $<0.01$ highly statistically significant. Statistical analysis was performed using the standard computer statistical package ("SPSS Version 18.0 for Windows", 2011).

\section{RESULTS}

The descriptive statistics for PRO scores and pulmonary function tests for all 275 subjects are presented in Table 1. The total time required to complete the LCQ, dyspnea and fatigue scales and $15 \mathrm{D}$ questionnaire ranged from 30 to $40 \mathrm{~min}$.

Indicators for internal consistency are presented in Table 2. Cronbach's alpha of different LCQ scores ranged between 0.901 for physical domain and 0.951 for the total score.

Regarding the concurrent validity, we observed strong correlations (all in the expected directions) of all LCQ scores with all examined dyspnea and fatigue scores (Table 3). It was also the case with $15 \mathrm{D}$ scores. All correlations, as assessed by the Pearson's coefficient of linear correlaton, were highly statistically significant ( $<<0.001$ for all correlations). The highest correlation coefficients with all PROs' scores were noticed for the LCQ Physical domain score. They were particularly high with DAL scale and 15D (Pearson coefficient 0.636 and 0.632 , respectively).

As pulmonary sarcoidosis is thought to be an interstitial lung disease, the traditional primary endpoint that has been selected for clinical trials is the forced vital capacity (FVC) [38]. Its mean value in our study population was pretty high (108.52 \pm 17.40$)$ and only $5 \%$ of them had values $<80 \%$. However, when considering the restrictive pattern treshold of $\mathrm{FEV}_{1} / \mathrm{FVC}>80$ then we noticed that $38 \%$ of our patients had lung restriction. In addition, the disease may predominantly affect the airways in some of the patient population and
Table 2. Internal consistency of the LCQ scores 
Table 3. Concurrent validity of the Serbian version of the LCQ - Correlations of the LCQ scores with PROs scores and pulmonary function tests

$\mathrm{k}=$ Pearson coeffitient;

$\mathrm{p}=$ Probability;

FAS-TS = Fatigue Assessment Scale - Total score;

MRC = Modified Medical Research Council Dyspnea Scale;

Borg = Borg dyspnea categoryratio-10 scale;

DAL = List of Daily Activities;

$\mathrm{LCQ}=$ Leicester Cough Questionnaire;

$15 \mathrm{D}$ = Fifteen-dimensional measure of health-related quality of life;

FEV1 = Forced expiratory volume in one second;

FVC = Forced expiratory vital capacity;

$\mathrm{PEF}=$ Peak expiratory Flow;

DLCO = transfer factor of the lung for carbon monoxide.

\begin{tabular}{|c|c|c|c|c|c|}
\hline & & $\begin{array}{l}\text { LCQ - Physical } \\
\text { Domain Score }\end{array}$ & $\begin{array}{l}\text { LCQ - Psychological } \\
\text { Domain Score }\end{array}$ & $\begin{array}{l}\text { LCQ - Social } \\
\text { Domain Score }\end{array}$ & $\begin{array}{l}\text { LCQ - Total } \\
\text { Score }\end{array}$ \\
\hline \multirow{2}{*}{ MRC Score } & k & -.572 & -.482 & -.500 & -.543 \\
\hline & $\mathrm{p}$ & .000 & .000 & .000 & .000 \\
\hline \multirow{2}{*}{ Borg Scale Score } & k & -.589 & -.507 & -.555 & -.579 \\
\hline & $\mathrm{p}$ & .000 & .000 & .000 & .000 \\
\hline \multirow{2}{*}{ FAS Total Score } & k & -.476 & -.358 & -.429 & -.440 \\
\hline & $\mathrm{p}$ & .000 & .000 & .000 & .000 \\
\hline \multirow{2}{*}{ DAL Score } & k & -.636 & -.506 & -.570 & -.596 \\
\hline & $\mathrm{p}$ & .000 & .000 & .000 & .000 \\
\hline \multirow{2}{*}{ 15D Score } & k & .632 & .508 & .562 & .594 \\
\hline & $\mathrm{p}$ & .000 & .000 & .000 & .000 \\
\hline \multirow{2}{*}{ FVC (L) } & k & .321 & .297 & .294 & .324 \\
\hline & $\mathrm{p}$ & .000 & .000 & .000 & .000 \\
\hline \multirow{2}{*}{ FVC (\%) } & k & .134 & .128 & .142 & .141 \\
\hline & $\mathrm{p}$ & .027 & .040 & .020 & .021 \\
\hline \multirow{2}{*}{ FEV1 (L) } & k & .340 & .303 & .317 & .334 \\
\hline & $\mathrm{p}$ & .000 & .000 & .000 & .000 \\
\hline \multirow{2}{*}{ FEV1 (\%) } & k & .187 & .174 & .199 & .186 \\
\hline & $\mathrm{p}$ & .002 & .004 & .001 & .002 \\
\hline \multirow{2}{*}{ FEV1/FVC } & k & .186 & .172 & .211 & .180 \\
\hline & $\mathrm{p}$ & .002 & .004 & .000 & .003 \\
\hline \multirow{2}{*}{ PEF (L) } & k & .310 & .276 & .289 & .300 \\
\hline & $\mathrm{p}$ & .000 & .000 & .000 & .000 \\
\hline \multirow{2}{*}{ PEF (\%) } & k & .219 & .211 & .218 & .212 \\
\hline & $\mathrm{p}$ & .000 & .000 & .000 & .000 \\
\hline \multirow{2}{*}{ DLCO } & k & .403 & .465 & .409 & .439 \\
\hline & $\mathrm{p}$ & .025 & .008 & .022 & .013 \\
\hline \multirow{2}{*}{ DLCO (\%) } & k & .389 & .418 & .440 & .430 \\
\hline & $\mathrm{p}$ & .031 & .019 & .013 & .016 \\
\hline
\end{tabular}

cause significant airflow obstruction as measured with the criterion $\mathrm{FEV}_{1} / \mathrm{FVC}<70$ [38]. In our study group there were $17 \%$ of patients with obstructive pattern. Correlations of the LCQ scores with all spirometry parameters were statistically significant, but weaker than with the PROs scores. The strongest correlations were noticed for the parameter FEV .

Transfer factor of the lung for carbon monoxide was performed in only 31 subjects, since in comparison with spirometry this test is not routinely assessed in all sarcoidosis patients. Correlations of the LCQ scores with DLCO values were stronger than with spirometric parameters.

\section{DISCUSSION}

Incorporation of PROs is very important in designing of the clinical trials protocols, especially in chronic diseases like sarcoidosis where objective outcomes cannot fully direct treating physicians in therapeutic decision making and follow up of their patients. Potential endpoints in sarcoidosis research should include: QoL measures, symptoms of cough, dyspnea, and wheeze, the frequency of disease exacerbations (requiring corticosteroid bursts or additional anti-sarcoidosis therapy), and corticosteroid-sparing effects of interventions [38].

In this study, we translated the LCQ 


\begin{tabular}{|l|c|c|c|c|c|c|c|}
\hline \multicolumn{1}{|c|}{} & $\begin{array}{c}\text { English } \\
\text { LCQ - } \\
\text { LCQ Scones } \\
\text { Chronic } \\
\text { cough [6] }\end{array}$ & $\begin{array}{c}\text { Dutch } \\
\text { LCQ - } \\
\text { Chronic } \\
\text { cough } \\
{[10]}\end{array}$ & $\begin{array}{c}\text { Dutch } \\
\text { LCQ - } \\
\text { COPD } \\
{[121]}\end{array}$ & $\begin{array}{c}\text { Polish } \\
\text { LCQ - } \\
\text { Chronic } \\
\text { cough } \\
{[12]}\end{array}$ & $\begin{array}{c}\text { Korean } \\
\text { LCQ - } \\
\text { Chronic } \\
\text { cough } \\
{[14]}\end{array}$ & $\begin{array}{c}\text { German } \\
\text { LCQ - } \\
\text { Sarcoidosis } \\
{[8]}\end{array}$ & $\begin{array}{c}\text { Serbian } \\
\text { LCQ - } \\
\text { Sarcoidosis }\end{array}$ \\
\hline Total & 0.92 & 0.93 & 0.86 & 0.89 & 0.91 & $/$ & 0.95 \\
\hline Physical & 0.79 & 0.77 & 0.67 & 0.82 & 0.84 & 0.87 & 0.90 \\
\hline Psychological & 0.89 & 0.84 & 0.75 & 0.86 & 0.86 & 0.94 & 0.92 \\
\hline Social & 0.85 & 0.83 & 0.74 & 0.78 & 0.87 & 0.92 & 0.92 \\
\hline
\end{tabular}

into Serbian language, and examined its psychometric properties in a sarcoidosis cohort.

Internal consistency, as assessed by the Cronbach's alpha coefficient, of different LCQ scores were between 0.901 (for Physical domain) and 0.951 (for Total score). Cronbach's alpha values between 0.7 and 0.8 can be considered as good, values between 0.90 and 0.95 as excellent. Values higher than 0.95 indicate item redundancy $[39,40]$. So, reliability of the Serbian verssion of the LCQ proved to be excellent. The subscale "physical" was the one with the weakest performance regarding internal consistency and it is in accordance with the results of Schupp and coauthors who validated the German version of the LCQ among 200 sarcoidosis patients [8]. Cronbach's alpha coefficients were similar with those in our study. Moreover, in other studies that validated the LCQ $[6,10,12,14]$, Cronbach's alpha values were also the lowest for Physical domain (Table 4). On the other hand, Cronbach's alpha values were highest for Psychological domain of the LCQ.

Concurent validity proved to be strong when LCQ scores were compared to the severity of the most frequent symptoms of sarcoidosis patients - dyspnea and fatigue, as well as to their general healt as assessd by the 15D questionnaire. In other publish studies $[12,13,16,19,41]$ correlations between LCQ scores and different PROs (mainly genetic QoL instruments) were mostly moderate as it was also the case with the original LCQ validation [6].

Concurent validity of the Polish LCQ [12] was tested in chronic cough patients population by comparing it with frequently used PROs - the respiratory-specific St. George's Respiratory Questionnaire (SGRQ) [42, 43], generic QoL instruement Euro-Quality of Life Questionnaire (EQ-5D) [44] together with its related Visual Analogue Scale (EQ5D-VAS), and Hospital Anxiety and Depression Scale
(HADS) [45]. All correlations were significant, except for those with the HADS. The strongest correlations of total LCQ scores were noticed with the generic EQ-5D questionnaire (Spearman's coefficient was $-0.49, \mathrm{p}=0.002$ ), that is in accordance with the result of our study when the total LCQ scores were compared with scores of generic 15D insturment (Pearson's coefficient $0.59, \mathrm{p}<0.001$ ).

Similar degree of correlation was seen during the validation of Korean LCQ [14] was compared with the most commonly used generic health status questionnarioe SF-36 (Spearman's correlation coefficient for total scores was $0.55, \mathrm{P}<0.0001)$ [46].

Berkhof et al [21] validated the Dutch version of the LCQ in COPD patients and assessed concurent validity comparing it with the SGRQ and SF-36 scores. Their results were in accordance with other autohors, with expected stronger correlations noticed with SGRQ than with SF-36.

In the other study of validation of the Durch LCQ in chronic cough patients Huisman and coauthors [10] compared its scores 36 scores were statistically significant, and it was also the case for HADS that was different from results in the study of Dąbrowska and coworkers [12].

LCQ scores in our study significantly correlated with all pulmonary function parameters. However, correlations of LCQ scores and pulmonary function tests in different patients' populations were not frequently performed. Judson et al found that cough was not statistically significantly different in terms of spirometric measures $\left(\mathrm{FEV}_{1} \%, \mathrm{FVC} \%\right.$ and $\mathrm{FEV}_{1} / \mathrm{FVC}$ ) [7].

Spanish study of LCQ validation in children with cystic fibrosis [22] correlated its scores with disease-specific QoL questionnaire „Cystic Fibrosis Questionnaire-Revised“ among patients wiht chronic cough, where it with SF-36 and HADS. Correlations with SF-
Table 4. Comparison of internal reliability of different versions of LCQ 
(CFQ-R) [47] and spirometry parameters $\mathrm{FEV}_{1}$ and FVC. All these correlations were statistically significant. The degree of correlation with spirometry parameters was higher than in our study for patients with sarcoidosis.

\section{CONCLUSION}

We conclude that the Serbian version of LCQ is a valid instrument for monitoring the influence of chronic cough on QoL in sarcoidosis patients. In comparison to other versions translated to other languages, its psychometric charactersistics are similar and we can recommend its use in clinical practice and research in sarcoidosis patients.

\section{FUNDING}

Authors did not receive any funds for this study.

\section{CONFLICTS OF INTEREST}

None of the authors disclosed any potential conflicts of interest.

\section{REFERENCES}

1. Hunninghake GW, Costabel U, Ando M et al. ATS/ ERS/WASOG statement on sarcoidosis. American Thoracic Society/European Respiratory Society/ World Association of Sarcoidosis and other Granulomatous Disorders. Sarcoidosis Vasc Diffuse Lung Dis 1999; 16:149-73.

2. Michielsen HJ, Peros-Golubicic T, Drent $M$ et al. Relationship between symptoms and quality of life in a sarcoidosis population. Respiration 2007; 74:401-5.

3. Vučinić V, Stojković M, Milenković B, ŠkodrićTrifunović V, Žugić V, Videnović-Ivanov J, et al. Fatigue in Sarcoidosis: Detection and Treatment. Srp Arh Celok Lek 2012; 139:104-9.

4. Food and Drug Administration (FDA). Draft Guidance for Industry. Patient-reported outcome measures: use in medical product development to support labeling claims. Rockville, MD, Dec 2009.

5. Gvozdenovic BS, Mihailović-Vučinić $V$, Vuković $M$, Lower EE, Baughman RP, Dudvarski-llic A, Zugic V, Popevic S, Videnovic-Ivanov J, Filipovic S, Stjepanovic $M$, Omcikus $M$. Effect of obesity on patient reported outcomes in sarcoidosis. Int J Tuberc Lung Dis 2013; 17(4):559-64.

6. Birring SS, Prudon B, Carr A.J, Singh SJ, Morgan MDL, Pavord ID. Development of a symptom specific health status measure for patients with chronic cough: Leicester Cough Questionnaire (LCQ). Tho$\operatorname{rax} 2003$; 58:339-43.

7. Judson MA, Chopra A, Conuel E, Koutroumpakis E, Schafer C, Austin A, et al. The Assessment of Cough in a Sarcoidosis Clinic Using a Validated instrument and a Visual Analog Scale. Lung 2017; 195(5):587-94.

8. Schupp JC, Fichtner UA, Frye BC, Heyduck-Weides K, Birring SS, Windisch W, et al. Psychometric properties of the German version of the Leicester Cough Questionnaire in sarcoidosis. PLoS One 2018; 13(10):e0205308.

9. Pirozzi CS, Mendoza DL, Xu Y, Zhang Y, Scholand MB, Baughman RP. Short-Term Particulate Air Pollution Exposure is Associated with Increased Severity of Respiratory and Quality of Life Symptoms in Patients with Fibrotic Sarcoidosis. Int J Environ Res Public Health 2018; 15(6):E1077.

10. Huisman AN, Wu MZ, Uil SM, van den Berg JWK. Reliability and validity of a Dutch version of the Leicester Cough Questionnaire. Cough 2007; 3:3.

11. Merkytè I, Bieksïienè K, Vagulienè N, Sakalauskas R. Reliability and Validity of a Lithuanian version of Leicester Cough Questionnaire. J Lung, Pulm Respir Res MedCrave Online; 2016; 3(5):1-3. https: //medcraveonline.com/JLPRR/JLPRR-03-00099

12. Dabrowska M, Krakowiak K, Radlińska O, Rybka A, Grabczak EM, Maskey-Warzęchowska M, et al. Validation of the Polish Version of the Chronic Cough Quality of Life Questionnaire (Leicester Cough Questionnaire). Adv Clin Exp Med 2016; 25(4):649-53.

13. Kwon JW, Moon JY, Kim SHSHSH, Song WJ, Kim $M H$, Kang MG, et al. Reliability and Validity of a Korean Version of the Leicester Cough Questionnaire. Allergy Asthma Immunol Res 2015; 7(3):230-3.

14. Han JM, Jung IC, Kang W, Kim SS, Yeo Y, Park YC. Reliability and validity of Leicester Cough Questionnaire Korean version. Chron Respir Dis 2014; 11(3):147-52.

15. Felisbino MB, Steidle LJM, GoncËalves-Tavares M, Pizzichini MMM, Pizzichini E. Leicester Cough Questionnaire: translation to Portuguese and crosscultural adaptation for use in Brazil. J Bras Pneumol 2014; 40(3):213-21.

16. Gao YH, Guan WJ, Xu G, Gao Y, Lin ZY, Tang Y, et al. Validation of the Mandarin Chinese version of the Leicester Cough Questionnaire in bronchiectasis. Int J Tuberc Lung Dis 2014; 18(12):1431-7.

17. Muñoz G, Buxô̂ M, de Gracia J, Olveira C, Martinez-Garcia MA, Giron R, et al. Validation of a Spanish version of the Leicester Cough Questionnaire in non-cystic fibrosis bronchiectasis. Chron Respir Dis 2016; 13(2):128-36.

18. Reychler G, Schinckus M, Fremault A, Liistro G, Pieters T. Validation of the French version of the Leicester Cough Questionnaire in chronic obstruc- 
tive pulmonary disease. Chron Respir Dis 2015; 12(4):313-9.

19. Pornsuriyasak $P$, Kawamatawong $T$, Rattanasiri S, Tantrakul V, Pongmesa T, Birring SS, et al. Validity and Reliability of Thai Version of the Leicester Cough Questionnaire in Chronic Cough. Asian Pacific J Allergy Immunol 2016; 34(3):212-6.

20. Murray MP, Turnbull K, MacQuarrie S, Pentland JL, Hill AT. Validation of the Leicester Cough Questionnaire in non-cystic fibrosis bronchiectasis. Eur Respir J 2009; 34(1):125-31.

21. Berkhof FF, Boom LN, ten Hertog NE, Uil SM, Kerstjens HA, Wk Van Den Berg J, et al. The validity and precision of the leicester cough questionnaire in COPD patients with chronic cough. Health Qual Life Outcomes 2012; 10:4.

22. Del Corral T, Percegona J, Lopez N, Valiente A, Garriga M, Seborga M, et al. Validity of a Spanish Version of the Leicester Cough Questionnaire in Children With Cystic Fibrosis. Arch Bronconeumol 2016; 52(2):63-9.

23. Medical Research Council. Questionnaire on Respiratory Symptoms: instructions to interviewers. MRC Committee on Environmental and Occupational Health. London: MRC, 1986.

24. Borg GA. Psychophysical bases of perceived exertion. Med Sci Sports Exerc 1982; 14(5):377-81.

25. Michielsen HJ, De Vries J, Van Heck GL. Psychometric qualities of a brief self-rated fatigue measure: the Fatigue Assessment Scale (FAS). J Psychosom Res 2003; 54:345-52.

26. Stewart AL, Ware JE, Brook RH. Advances in the measurement of functional status: constructioon of aggregate indexes. Med Care 1981;19:473-88.

27. Sintonen $\mathrm{H}$, Pekurinen $\mathrm{M}$. A fefteen-dimensional measure of health-related quality of life (15D) and its applications. In Walker SR, Rosser R, eds. Quality of life assessment: key issues in 1990s. Dordrecht: Kluwer Academic Publishers, 1993:185-95.

28. Gvozdenovic BS, Mihailovic-Vucinic V, IlicDudvarski A, Zugic V, Judson MA. Differences in symptom severity and health status impairment between patients with pulmonary and pulmonary plus extrapulmonary sarcoidosis. Respir Med 2008; 102(11):1636-42.

29. Gvozdenovic BS, Mihailovic-Vucinic V, Videnovic J, Zugic V, llic-Dudvarski A, Filipovic S. Quality of life and health status in sarcoidosis patients. Chapter 6. In: Hoffmann EC, ed. Health-related quality of life. New York: Nova Science Publishers, Inc., 2009:119-32.

30. Michielsen HJ, De Vries J, Van Heck GL, Van de Vijver FJR, Sijtsma K. Examination of the dimensionality of fatigue: the construction of the Fatigue Assessment Scale (FAS). Eur J Psychol Assess 2004; 20(1):39-48.
31. Drent M, Lower EE, De Vries J. Sarcoidosis-associated fatigue. Eur Respir J 2012; 40(1):255-263.

32. Lapčević M, Vuković $M$, Gvozdenović BS, Mioljević V, Marjanović S. Socioeconomic and therapy factor influence on self-reported fatigue, anxiety and depression in rheumatoid arthritis patients. Rev Bras Reumatol 2017; 57(6):545-556.

33. Vucinic V, Patel AS, Birring SS, Gvozdenovic BS, Vukovic M, Videnovic-Ivanov J, et al. King's Sarcoidosis Questionnaire (KSQ): New instrument for assessing health status in sarcoidosis: the relationship between KSQ and other health status questionnaires. [Abstract SAR 37] Abstracts from the 6th International WASOG Conference on Diffuse Parenchymal Lung Diseases, June 6-7 2013, Paris, France, 2013:90.

34. Schrier AC, Dekker FW, Kaptein AA, Dijkman JH. Quality of life in elderly patients with chronic nonspecific lung disease seen in family practice. Chest 1990; 98(4):894-9.

35. Gvozdenović BS, Mitić S, Žugić VG, Gvozdenović AT, Lazović NM, Plavšić S. Relationship between the degree of dyspnea and health-related quality of life in patients with chronic obstructive pulmonary disease. Srp Arh Celok Lek 2007; 135(9-10):547-53.

36. Gvozdenovic BS, Mihailovic-Vucinic V, Vukovic M, Lapcevic M, Zugic V, Videnovic J, Filipovic S, IlicDudvarski A. Predictors of health status and symptoms impairment in sarcoidosis patients. Chapter 5. In: Connor MR and Stevens RS, eds. Sarcoidosis: Diagnosis, Epidemiology and Treatment Options. New York: Nova Science Publishers, Inc., 2012:95-110.

37. Miller MR, Hankinson J, Brusasco V, Burgos F, Casaburi R, Coates A, et al. Standardisation of spirometry. Eur Respir J 2005; 26: 319-38.

38. Judson MA. Endpoints in sarcoidosis: More like IPF or asthma? Respir Med 2018; 138S:S3-S4.

39. Lim L, Seubsman S, Sleigh A. Thai SF-36 health survey: tests of data quality, scaling assumptions, reliability and validity in healthy men and women. Health Qual Life Outcomes. BioMed Central; 2008; $6: 52$.

40.Terwee CB, Bot SDM, de Boer MR, der Windt DAWM, Knol DL, Dekker J, et al. Quality criteria were proposed for measurement properties of health status questionnaires. J Clin Epidemiol 2007; 60(1):34-42.

41. Sönnerfors P, Faager G, Einarsson U. Translation of the Leicester Cough Questionnaire into Swedish, and validity and reliability in chronic obstructive pulmonary disease, Disability and Rehabilitation 2018; 40(22):2662-70.

42. Jones PW, Quirk FH, Baveystock CM, Littlejohns P. A self-complete measure of health status for chronic airflow limitation. The St. George's Respiratory Questionnaire. Am Rev Respir Dis 1992; 145(6):1321-7. 
43. Zugic V, Videnovic-Ivanov J, Gvozdenovic B. St. George's Respiratory Questionnaire (SGRQ) in sarcoidosis patients. Med Pregl 2005; 58(Suppl 1):71-4.

44. Brooks R. The current state of play. Health Policy 1996; 37(1):53-72. http: / /www.euroqol.org.

45. Zigmond AS, Snaith RP. The hospital anxiety and depression scale. Acta Psychiatr Scand 1983, 67(6):361-7.

46. Ware JE, Sherbourne CD. A 36-item Short-Form Health Survey (SF-36): conceptual framework and item selection. Med Care 1992; 30(6):473-83.

47. Henry B, Aussage P, Grosskopf C, Goehrs JM. Development of the Cystic Fibrosis Questionnaire (CFQ) for assessing quality of life in pediatric and adult patients. Qual Life Res 2003; 12(1):63-76. 


\section{Psihometrijske karakteristike srpske verzije lesterskog upitnika o kašlju kod bolesnika sa sarkoidozome}

Branislav S. Gvozdenović́ ${ }^{1}$, Violeta V. Mihailović-Vučiniće, ${ }^{2,3}$, Mira H. Vuković4, Mihailo I. Stjepanoviće, ${ }^{2,}$ Strahinja V. Mihailović ${ }^{2}$ Nikola B. Marić ${ }^{2}$

\footnotetext{
${ }^{1}$ PPD Serbia, Služba za farmakovigilancu, Beograd, Srbija

${ }^{2}$ Klinika za pulmologiju, Klinički centar Srbije, Beograd, Srbija

${ }^{3}$ Medicinski fakultet, Univerzitet u Beogradu, Beograd, Srbija

${ }^{4}$ Odeljenje za obezbeđenje kvaliteta, Bolnica Valjevo, Valjevo, Srbija
}

\section{KRATAK SADRŽAJ}

Uvod: Kašalj je čest simptom u sarkoidozi i trenutno u Srbiji ne postoji specifičan instrument za merenje njegove težine.

Cilj: Cilj ove studije je bio da se prevede i validira srpska verzija Lesterskog upitnika o kašlju (engl. Leicester Cough Questionnaire, LCQ) u populaciji pacijenata sa sarkoidozom.

Metodologija: Nakon postupka prevođenja LCQ, u studiji preseka 275 pacijenata sa sarkoidozom (od toga 180 osoba ženskog pola) je popunilo srpsku verziju LCQ zajedno sa ostalim standardizovanim upitnicima za merenje ishoda saopštenih od strane pacijenta (eng. Patient Reported Outcomes, PROs) - simptoma dispneje (korišćenjem MRC i Borgove skale), zamora (merenim "Skalom za procenu zamora" i "Listom dnevnih aktivnosti") i zdravstvenog statusa pacijenata (procenjenim generičkim upitnikom 15D). Takođe je sprovedeno merenje testova plućne funkcije (spirometrija i difuzijski kapacitet pluća za ugljen-monoksid).

Rezultati: Srpska verzija LCQ ima odličnu internu konzistentnost (koeficijent Krombah alfa se kretao između 0,901 za oblast fizičkih aktivnosti upitnika i 0,951 za njegov totalni skor). Konkurentna validnost LCQ procenjena je stepenom povezanosti njegovih skorova sa skorovima drugih ispitivanih PROs i vrednostima testova plučne funkcije i pokazala se kao veoma dobra s obzirom na to da su sve pomenute korelacije bile statistički značajne.

Zaključak: Naši rezultati su potvrdili da srpska verzija LCQ predstavlja validan instrument za merenje uticaja hroničnog kašlja na kvalitet života bolesnika sa sarkoidozom.

Ključne reči: sarkoidoza, kašalj, dispneja, zamor, testovi plućne funkcije 